\title{
Development of a HPLC/MS/MS methodology for determining 3-O-methyldopa in human plasma and its application in a bioequivalence study
}

\author{
Desenvolvimento de metodologia baseada em HPLC/MS/MS para a \\ determinação de 3-O-metildopa em plasma humano e sua aplicação a \\ estudos de bioequivalência
}

RIALA6/1593

\author{
Heliana Figueiredo MARTINS ${ }^{1}$, Douglas Pereira PINTO' ${ }^{1}$, Viviane de Assis NASCIMENTO ${ }^{1}$, Marlice Aparecida Sipoli \\ MARQUES², Fábio Coelho AMENDOEIRA ${ }^{3 *}$ \\ ${ }^{*}$ Correspondence Adress: ${ }^{3}$ Laboratório de Farmacologia, Departamento de Fisiologia e Farmacodinâmica, Instituto \\ Nacional de Controle de Qualidade em Saúde, Fundação Oswaldo Cruz. Av. Brasil 4365, Manguinhos, Rio de Janeiro, RJ, \\ Brazil, CEP 21040-900.eE-mail: fabio.amendoeira@incqs.fiocruz.br \\ ${ }^{1}$ Laboratório de Farmacocinética, Fundação Oswaldo Cruz, Rio de Janeiro, RJ, Brazil \\ ${ }^{2}$ Departamento de Química Analítica, Instituto de Química (IQ), Universidade Federal do Rio de Janeiro (UFRJ), Rio de \\ Janeiro, RJ, Brazil \\ Recebido: 10.09.2013 - Aceito para publicação: 31.03.2014
}

\begin{abstract}
A simple, sensitive and specific HPLC/MS/MS methodology was developed and it was validated for determining 3-O-methyldopa, the major metabolite of dopamine, in human plasma. The separation was achieved on Atlantis T3 C18 analytical column ( $5 \mu \mathrm{m} ; 150 \times 4.6 \mathrm{~mm}$ i.d.) using a mobile phase consisted of a solution of water and methanol $(85: 15, \mathrm{v} / \mathrm{v})$ and containing formic acid $0.05 \%$. The extraction from the analyte and the internal standard sample was performed using a simple protein plasma precipitation with perchloric acid. The detection was conducted on a triple quadrupole tandem mass spectrometer with a positive multiple reaction monitoring mode (MRM). The monitored fragmentation transitions were $\mathrm{m} / \mathrm{z}$ $212.0 \rightarrow \mathrm{m} / \mathrm{z} 166.0$ for 3-O-methyldopa and $\mathrm{m} / \mathrm{z} 227.10 \rightarrow \mathrm{m} / \mathrm{z} 181.0$ for carbidopa (internal standard). The calibration curves were linear in the range of $50-4000 \mathrm{ng} / \mathrm{mL}$ for 3-O-methyldopa. The methodology presented a good precision and accuracy in accordance to the criteria for biomedical analysis. And it was successfully applied to the bioequivalence study of two formulations levodopa + benserazide $(200+50$ $\mathrm{mg}$ ) in plasma samples from healthy human volunteers, following the ANVISA guidelines.
\end{abstract}

Keywords. 3-O-methyldopa, HPLC-ESI-MS/MS, bioequivalence, plasma, pharmacokinetics.

\section{RESUMO}

Uma metodologia específica, simples e sensível baseado em HPLC/MS/MS foi desenvolvida e validada para realizar a determinação de 3-o-metildopa, o principal metabolito da dopamina, em plasma humano. A separação foi realizada em coluna analítica Atlantis T3 C18 (5 $\mu \mathrm{m} ; 150$ x 4,6 mm i.d.), utilizando-se uma fase móvel composta por uma solução de água e metanol (85:15, v/v), e contendo 0,05\% de ácido fórmico. A extração do analito e da amostra padrão interno foi executada utilizando-se uma simples precipitação proteica no plasma com ácido perclórico. A detecção foi realizada por meio de espectrômetro de massa triplo quadrupolo, em modo de monitoramento de reações múltiplas (MRM) positivo. A transição monitorizada foi $\mathrm{m} / \mathrm{z}$ 212,0 $\rightarrow \mathrm{m} / \mathrm{z}$ 166,0 para 3-O-metildopa e m/z 227,1 $\rightarrow \mathrm{m} / \mathrm{z}$ 181,0 para carbidopa (padrão interno). As curvas de calibração foram lineares na faixa de 50 a $4000 \mathrm{ng} / \mathrm{mL}$ para 3-O-metildopa. A metodologia apresentou boa precisão e exatidão de acordo com os critérios para análises biomédicas e esta foi aplicada com sucesso no estudo de bioequivalência de duas formulações contendo levodopa + benserazida $(200+50 \mathrm{mg})$ em amostras de plasmas humanos.

Palavras-chave. 3-O-metildopa, HPLC-ESI-MS/MS, bioequivalência, plasma, farmacocinética. 


\section{INTRODUCTION}

Parkinson's disease is a neurodegenerative disorder characterized by progressive loss of dopaminergic neurons in the substantia nigra. It affects the mobility and control of the skeletal muscular system and is characterized by tremor, rigidity, bradykinesia and postural instability that affects $0.3 \%$ of the general population and $1 \%$ to $2 \%$ of people $>60$ years $^{1-3}$.

Nowdays Levodopa still remains the most effective drug in the treatment of Parkinson's disease, however, most of administered levodopa is converted by aromatic L-amino acid decarboxylase to dopamine before it can enter the central nervous system ${ }^{1,3,4}$.

Therefore, $\mathrm{L}$-dopa is routinely given in association with peripheral aromatic-L-amino acid decarboxylase inhibitors, such as benserazide, that inhibit conversion of L-dopa peripherally, but do not easily cross the blood brain barrier to affect its conversion to dopamine centrally ${ }^{4,5}$.

In the central nervous system as well as in several other tissues L-dopa can be directly metabolized by catechol-O-methyl transferase (COMT) to 3-O-methyldopa (3-OMD). When L-dopa is administered with dopa decarboxylase inhibitors (DDI), such as benserazide, the availability of L-dopa in the brain increases dramatically, resulting in the accumulation of 3-OMD in this site ${ }^{6,7}$.

There is growing evidence that accumulation 3-OMD might be involved in the side effects of chronic treatment of L-dopa ${ }^{6,8}$.

There with measurements of levodopa and its metabolites in blood have been crucial for pharmacokinetic and bioequivalence studies of antiparkinson drugs containing levodopa associated with benserazide ${ }^{9,10}$.

Recently, several bioanalytical methods based on mass spectrometry for plasma quantification of Levodopa and its metabolites have been developed ${ }^{11-15}$ as well methods based on fluorimetric, ultraviolet or electrochemical detection ${ }^{3,10,12,15-18}$. Several studies performed using high performance liquid chromatography coupled to tandem mass spectrometry (HPLC-MS/MS) for the determination of drugs in biological fluids was recently developed ${ }^{19-21}$, however a few methods to determine 3-OMD in human plasma using HPLC-MS/MS were developed and validated ${ }^{9}$. Therefore, further studies are necessary for development of new rapid and accurate quantitation techniques to the measurement of low concentrations of 3-OMD in human plasma with high selectivity and sensitivity.

The aim of this work was to develop and validate an efficient bioanalytical method based on HPLC-ESIMS/MS for rapid and accurate quantification of 3-OMD in human plasma and apply it to a bioequivalence study.

\section{MATERIAL AND METHODS}

\section{Materials}

3-OMD (Batch No. 1106062A3) was obtained from PGS (Carborro, USA) with 98.8 of purity and Carbidopa (CBDP, internal standard, I.S.) was purchased from the United States Pharmacopeia (Rockville, MD, USA) with $92.6 \%$ of purity. Analytical grade Methanol and Formic acid $96 \%$ was obtained from Tedia (Fairfield, $\mathrm{OH}$, United States). Double distilled water was purified by Millipore system (Bedford, MA, USA) and was used for all the experiments. All other chemicals and solvents were of the highest analytical grade available.

\section{Instrumentation and detection}

The HPLC Varian System (Walnut Creek, Califórnia, USA), equipped with two analytical pumps Varian 212-LC was employed. A HTS-CTC Analytics auto-injector was used. A triple-quadrupole tandem mass spectrometer (VARIAN 320 MS, Walnut Creek, Califórnia, USA) equipped with an electrospray ion source and operated in the positive ionization mode was used in this analysis. The ion spray voltage and source temperature were $5500 \mathrm{~V}$ and $400{ }^{\circ} \mathrm{C}$, respectively. The others parameters for the gas source were set as follow: drying gas $30 \mathrm{psi}$, nebulizer gas $55 \mathrm{psi}$, collision induced dissociation (CID) 2.00 mTorr. The collision energy for the 3-OMD and CBP were 10.5 and 10.0 $\mathrm{V}$, respectively. The voltage capillary applied was 30 $\mathrm{V}$ for analyte and internal standard. The parameters were optimized for best response by directly infusing standard solutions of 3-OMD and CBDP at flow rate of $20 \mu \mathrm{L} / \mathrm{min}$ through syringe pump. Quantification was performed using multiple reaction monitoring (MRM) of the fragmentation transitions $\mathrm{m} / \mathrm{z} 227.10 \rightarrow 181.0$ for carbidopa (Figure 1A) and $\mathrm{m} / \mathrm{z} 212.0 \rightarrow 166.0$ for 3-OMD (Figure $1 \mathrm{~B}$ ). Data acquisition and analysis were achieved using the Varian MS Workstation software (Version 6.6, Walnut Creek, USA). 


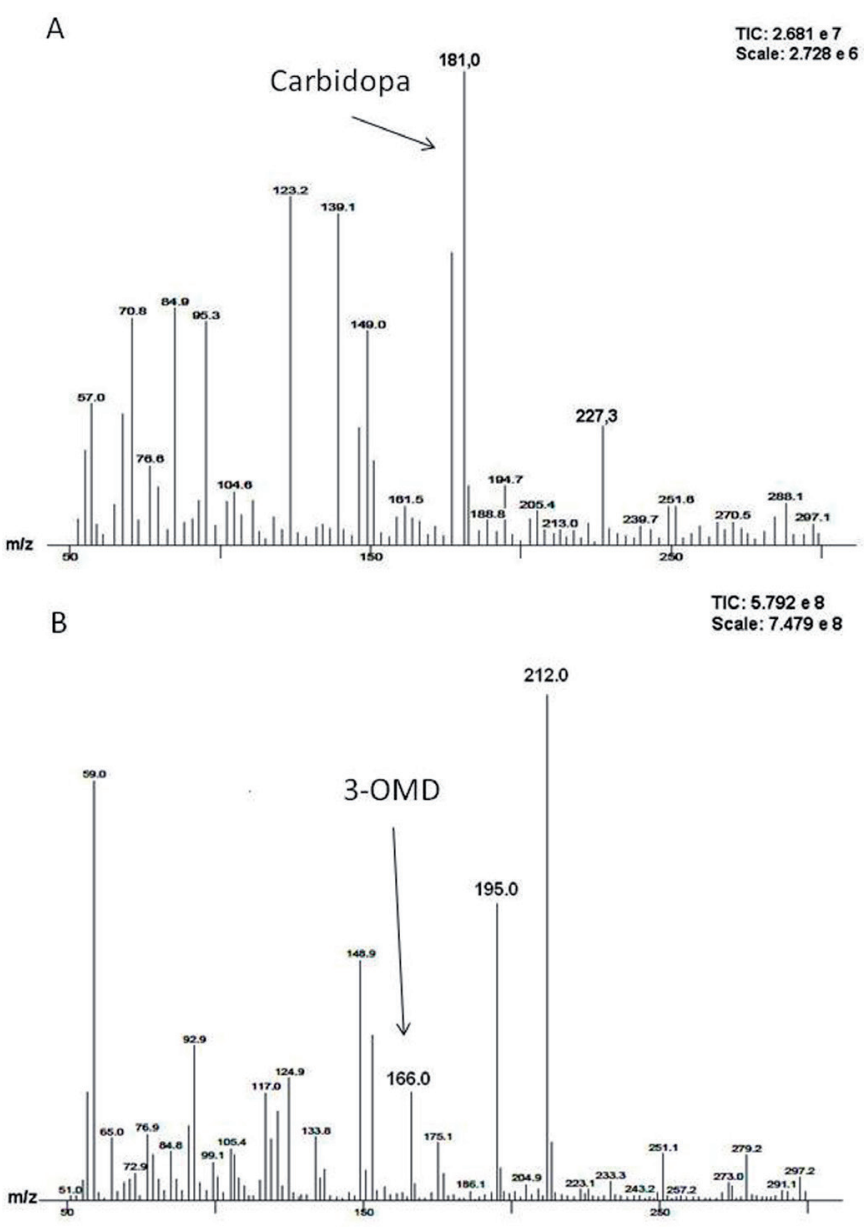

Figure 1. The íon product spectrum of (A) Carbidopa ( $\mathrm{m} / \mathrm{z} 181.0$ ) and (B) 3-OMD ( $\mathrm{m} / \mathrm{z} 166.0)$ obtained by electrospray ionization in positive íon mode

\section{Chromatographic conditions}

Atlantis T3 C18 (5 $\mu, 150 \times 4.6 \mathrm{~mm}$ i.d.) was selected as the reversed-phase analytical column. The mobile phase consisting of water and methanol (85:15, $\mathrm{v} / \mathrm{v}$ ) containing formic acid $0.05 \%$ was pumped at a flow rate of $1 \mathrm{~mL} / \mathrm{min}$ with flow divider split 1:1. The run time was $5.0 \mathrm{~min}$ and the injection volume was $20 \mu \mathrm{L}$ into HPLC-MS/MS system.

\section{Preparation of stock and working solutions}

Stock standard solutions of 3-OMD and CBDP (IS) were prepared by dissolving accurately weighed reference substances in methanol containing $0.04 \%$ of perchloric acid at a concentration of $1 \mathrm{mg} / \mathrm{mL}$. Either solutions were treated in an ultrasonic bath (Branson 2210 ultrasonic cleaner, Bransonic Ultrasonic Corporation, Darbury, CO, USA) for $5 \mathrm{~min}$. The standard working solutions of 3-OMD in the concentrations of 1000 , 2000, 5000, 10000, 15000, 30000, 60000 and $80000 \mathrm{ng} /$ $\mathrm{mL}$, were obtained by dilution of the stock solution with methanol/water (1:1 v/v). Quality control (QC) working solutions with concentrations of 1000, 2000, 30000 and $60000 \mathrm{ng} / \mathrm{mL}$ was prepared as the standard working solution. The working internal standard solution containing $4000 \mathrm{ng} / \mathrm{mL}$ of CBDP was also prepared in methanol and water $(1: 1 \mathrm{v} / \mathrm{v})$ by dilution of the stock solution. All solutions were stored at $-70{ }^{\circ} \mathrm{C}$ in amber glass bottle when not used.

\section{Sample preparation}

A $200 \mu \mathrm{L}$ sample of human plasma were added to $2.0 \mathrm{~mL}$ polypropylene tubes. To each tube $50 \mu \mathrm{L}$ of IS solution $(4000 \mathrm{ng} / \mathrm{mL}$ of CBDP in methanol/water $(1: 1 \mathrm{v} / \mathrm{v})$ and $240 \mu \mathrm{L}$ and $0.4 \mathrm{M}$ of perchloric acid were added to the protein precipitation. The tubes were stirred with the vortex for approximately $1 \mathrm{~min}$ followed by centrifugation at $20093 \mathrm{~g}$ for $15 \mathrm{~min}$, at -5 ${ }^{\circ} \mathrm{C}$. The extract of sample plasma was transferred to an autosampler vial containing $300 \mu \mathrm{L}$ of water / formic acid $0.05 \%$ and was vortexed for $20 \mathrm{~s}$. Aliquots $(20 \mu \mathrm{L})$ from the final extract were injected into the HPLC-MS/ MS system for analysis.

\section{Method validation and quantification}

The validation process was carried out according to the Guidance given to the Industry - Bioanalytical Method Validation, recommended by US Food Drug Administration and according Resolution n. 899 of May 23, 2003 by Anvisa, Brazil22, the legislations in force at the time of the study. Currently studies of this nature should follow the Resolution RDC n. 27 of May 17, 2012 23.

\section{Recovery}

The recovery from human plasma was determined at three different concentrations ( $\mathrm{n}=3$ each) for 3-OMD and CBDP (IS) by comparing the peak areas obtained from analysis of eight replicates of plasma samples prepared according to the method of analysis versus absolute recovery solutions without plasma deriving from standard solutions with subsequent dilution to identical target concentrations of 100, 1500 and $3000 \mathrm{ng} / \mathrm{mL}$. The recovery of IS was determined in a similar way, at the working concentration (1000 ng/ $\mathrm{mL}$ of $\mathrm{CBDP})^{22}$. 


\section{Limit of quantification (LOQ)}

Peak response (peak area) was determined in blank plasma samples (six replicates from different plasma) and in spiked LOQ sample prepared from the same plasma. The peak area of blank samples should be no greater than $20 \%$ of the mean peak area of LOQ of $3-\mathrm{OMD}$, and no greater than $5 \%$ of CBDP. The precision and mean accuracy of the back calculated LOQ replicate concentrations must be $\leq 20$ and $\pm 20 \%$, respectively. The LLOQ was defined and established in $50 \mathrm{ng} / \mathrm{mL}$. To accept the LLOQ value, the peak of the analyte at this concentration should be at least 5 times the baseline noise. In addition, each LLOQ sample should be obtained with an acceptable accuracy as relative error (RE) within $\pm 20 \%$ and a precision (RSD) not exceeding $20 \%$.

\section{Limit of detection (LOD)}

According to Resolution n. 899/2003 Anvisa, the limit of detection should be established through the analysis of solutions of known and decreasing drug concentrations to the lowest detectable level. It is recommended that the LOD is 2 to 3 times the baseline noise. In the analytical method of the baseline noise was determined in a range of 5 absolut counts, which set limits in terms of detection a value corresponding to $15 \mathrm{ng} / \mathrm{mL}$.

\section{Analytical curves, regression model}

The analytical curves were constructed using values ranging from 50 to $4000 \mathrm{ng} / \mathrm{mL}$ of $3-\mathrm{OMD}$ in human plasma. Calibration curves were obtained by the weighted linear model. The ratio of 3-OMD peak area to CBDP peak area was plotted against 3 -OMD concentration in $\mathrm{ng} / \mathrm{mL}$. The suitability of the calibration curve was confirmed by back-calculating the concentrations of the calibration standards.

$$
\begin{aligned}
& y=a\left(x_{2}\right)+b(x) \\
& y=\text { peak area ratio (PAR) of 3-OMD to CBDP } \\
& x=\text { concentration }(n g / m L) \text { of 3-OMD in plasma. } \\
& \text { Coefficients } a, b \text {, the coefficient of determination }
\end{aligned}
$$

$\left(\mathrm{r}_{2}\right)$ and $\mathrm{x}$ was calculated using weighted 1 linear model with regression analysis.

\section{Calibration curve standards and quality control samples}

The linearity of the method was assessed by analyzing calibration standard plasma samples containing levodopa at 8 different concentrations in duplicate. The concentration range evaluated to $3-\mathrm{OMD}$, was 50, 100,
$250,500,750,1500,3000$ and $4000 \mathrm{ng} / \mathrm{mL}$ by using a weighted $\left[1 / x^{2}\right]$ least-squares linear regression analysis method. The calibration standards were prepared by spiking $950 \mu \mathrm{L}$ drug-free human plasma with $50 \mu \mathrm{L}$ of 3 -OMD standard work solutions. Then $200 \mu \mathrm{L}$ of spiked plasma were transferred to a $2.0 \mathrm{~mL}$ polypropylene tube and processed as described above.

The QC samples were prepared according to the same procedure described for the calibration standards using blank plasma, fortified at 50, 100, 1500 and 3000 $\mathrm{ng} / \mathrm{mL}$ of $3-\mathrm{OMD}$ and $1000 \mathrm{ng} / \mathrm{mL}$ of CBDP (IS). The calibration curves and QC samples were freshly prepared and analyzed with each batch of human plasma.

\section{Precision and accuracy}

The precision and accuracy intra and inter-batch were assessed by using human plasma spiked with three different concentrations $(100,1500$ and $3000 \mathrm{ng} / \mathrm{mL})$ with replicate analysis $(n=8)$ on three consecutive days. The concentration of each sample was determined using freshly prepared calibration standards. The precision was expressed as the relative standard deviation (RSD) and the accuracy as relative error (RE) with an acceptable accuracy and precision within $\pm 15 \%{ }^{22}$.

\section{Stability}

The stability of 3-OMD were evaluated by analysis of QC samples at two concentrations of 100 and $3000 \mathrm{ng} / \mathrm{mL}$ in eight replicates. The autosampler's stability was also determined by analyzing extracted QC samples kept under autosampler conditions $\left(+7^{\circ} \mathrm{C}\right)$ for $48 \mathrm{~h}$. Room temperature stability and long-term stability were assessed using untreated QC samples kept at room temperature for $6 \mathrm{~h}$ and stored at $-70{ }^{\circ} \mathrm{C}$ for 683 days, respectively. After eight freezing/thaw cycles $\left(-70{ }^{\circ} \mathrm{C}\right.$ / room temperature) on consecutive days, QC samples were processed and analyzed to determine the freezethaw stability. Samples were considered to be stable if their assay values were within the range of $15 \%$ of the nominal values ${ }^{22}$.

Standard stock solution stability at room temperature in white light under laboratory conditions and refrigerated conditions for 3-OMD and CBDP was performed as part of the method development process.

\section{Specificity and carry-over}

The specificity was assessed by comparing chromatograms of six different batches of blank plasma, 
Martins HF, Pinto DP, Nascimento VA, Marques MAS, Amendoeira FC. Development of a HPLC/MS/MS methodology for determining 3-O-methyldopa in human plasma and its application in a bioequivalence study Rev Inst Adolfo Lutz. São Paulo, 2014; 73(1):96-105.

including one lipemic, one hemolysate and four normal plasmas from different sources. The chromatograms were compared with those obtained from the analysis of the mobile phase fortified with 3-OMD (50 ng/mL) and carbidopa $(1000 \mathrm{ng} / \mathrm{mL})$ to ensure no interference in the analyte analysis. The carryover was measured by comparing the peak areas of drug-free plasma injected after the sampling of $3-\mathrm{OMD}(4000 \mathrm{ng} / \mathrm{mL})$ by three consecutive times. The endogenous interference of the anticoagulant (heparin) in plasma samples was evaluated.

\section{Pharmacokinetics study}

The pharmacokinetics study was conducted in 60 healthy volunteers after a single-dose, randomized with 2-periods, crossover, of two formulations test and reference of levodopa + benserazide $(200+50 \mathrm{mg})$. The clinical study was conducted by a colaborative laboratory and its clinic protocol was approved by the Ethics Committee (license: 892/2008, Unicamp, Campinas São Paulo, Brazil,). All subjects gave written informed consent. The washout time between two periods was 9 days (216 hours). The blood samples were collected into amber tubes, using heparin as anticoagulant at pre-dose, $0.25,0.5,0.75,1,1.25,1.5,1.75,2,2.33,2.66,3,3.5,4$, $5,6,8,10,12,16,24,48,72,96$ and 120 h post-dosing. Samples were centrifuged at $4884 \mathrm{~g}$ for $10 \mathrm{~min}$ in $4{ }^{\circ} \mathrm{C}$ and the plasma was separated and stored at $-70{ }^{\circ} \mathrm{C}$ until analysis.

Pharmacokinetics parameters for the human plasma samples were calculated by a non-compartmental statistics model using WinNonlin ${ }^{\mathrm{TM}}$ program (Vesion 5.3, Microsoft excel, 2003). Plasma samples were taken for a period of 3 to 5 times under the concentration time curve (AUC) ratio higher than $80 \%$, as per FDA guidelines. Plasma 3-OMD concentration-time profiles were visually inspected, and $\mathrm{C}_{\max }$ and $\mathrm{T}_{\max }$ values were determined.

The $\mathrm{AUC}_{0-\mathrm{t}}$ was obtained by the trapezoidal method. $\mathrm{AUC}_{0-\infty}$ was calculated up to the last measureable concentration and extrapolations were obtained using the last measureable concentration, and the terminal elimination rate constant $\left(\mathrm{K}_{\mathrm{e}}\right)$. $\mathrm{K}_{\mathrm{e}}$ was estimated from the slope of the terminal exponential phase of the plasma of the 3-OMD concentration-time curve by the linear regression method. The terminal elimination half-life $t_{1 / 2}$, was then calculated as $0.693 / \mathrm{Ke}$. Regarding $\mathrm{AUC}_{0-\mathrm{t}}$, $\mathrm{AUC}_{0-\infty}$ and Cmax bioequivalence was assessed by analysis of variance (ANOVA) and by calculating the standard $90 \%$ confidence intervals (90\% CIs) of the ratio's test/reference (logarithmically transformed data). The bioequivalence was considered when the ratio of averages of log transformed data was within $80-125 \%$ for $\mathrm{AUC}_{0-\mathrm{t}}, \mathrm{AUC}_{0-\infty}$ and $\mathrm{C}_{\max }$.

\section{RESULTS AND DISCUSSION}

\section{Method development}

The MS spectra of 3-OMD and CBDP were recorded in positive ion mode. The best analysis conditions were achieved using a mixture of water/ methanol/formic acid at ratio of 85:15:0.0 5\% (v/v/v).

Different types of columns (Atlantis T3, Pursuit C18, OmniSpher C18, monoChrom 5 u MS) were evaluated and the Atlantis T3 column was selected due to the best chromatographic separation from endogenous compounds under our experimental conditions and contributed to significant reduction of matrix effect due to its high performance with low proportion of solvents in our experiments. The choice of the column also was based in the possibility of use high proportions of aqueous phase with water, which allows the best chromatographic peak shape. Other factor that also contributed for choice of analytical column was the $\mathrm{pH}$ of the plasma samples treated with perchloric acid in step of extraction.

In this study, neither additive was used to $\mathrm{pH}$ adjustment (neutralization) after precipitation of perchlorate in the extraction process, different from what the literature describes to similar procedures ${ }^{13,14}$.

The retention time and good peak shape of the analyte and internal standard on our analytical conditions, demonstrate the advantage of present high-throughput method when compared to similar extraction methods in recent literature $e^{9,10,13,18,24}$.

The literature shows that as methyldopa much as CBDP could be used as internal standards due to their chemical similarities to $3-\mathrm{OMD}$ and levodopa ${ }^{5}$. In our study, methyldopa could not be used as internal standard because your mass fragment are equal to monitored by 3-OMD.

Under the selected chromatographic conditions, CBDP was chosen as I.S. due to its high sensitivity, similar chromatographic and mass spectrometric behavior in relation to analyte. 3-OMD and CBDP was eluted and well resolved chromatographic at retention times of 4.06 min and $4.04 \mathrm{~min}$, respectively (Figure 2E and 2F). 


\section{Selectivity}

The analysis of the six different human blank plasma samples (one hemolysate, one lipemic and four normal) was evaluated by analyzing the specificity.

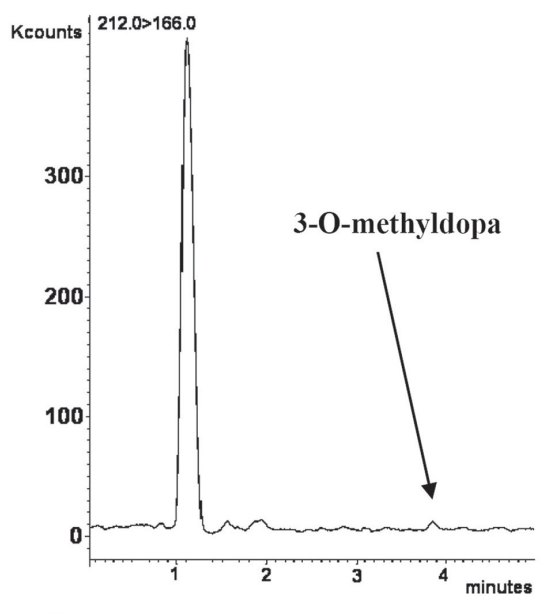

A

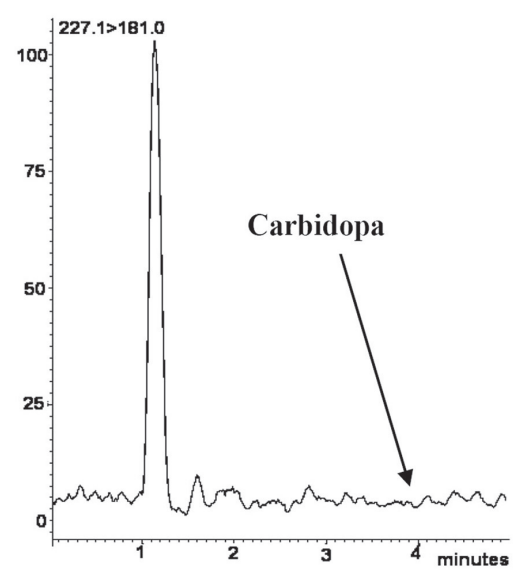

Kcounts
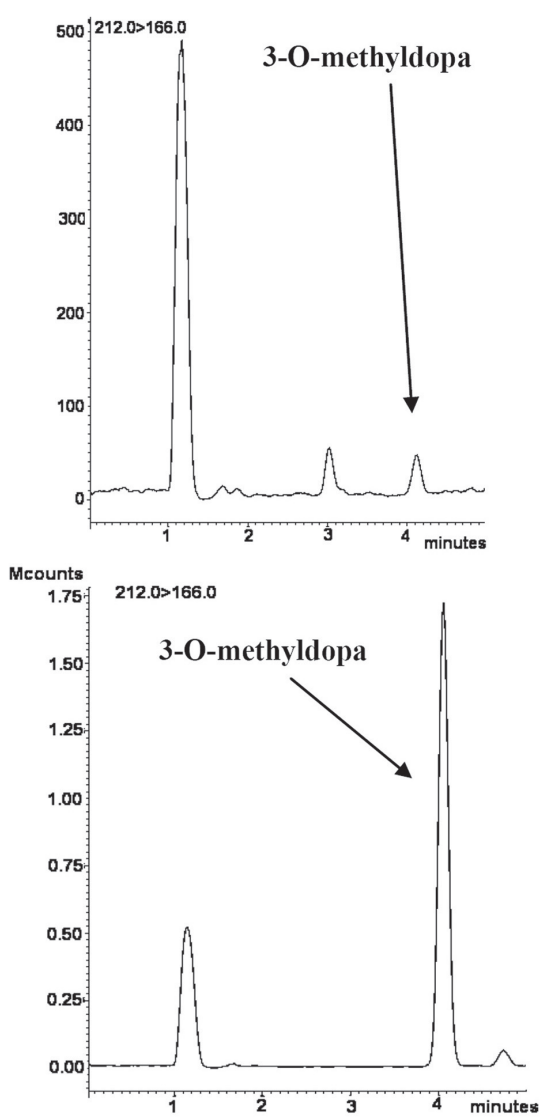

$\mathrm{C}$
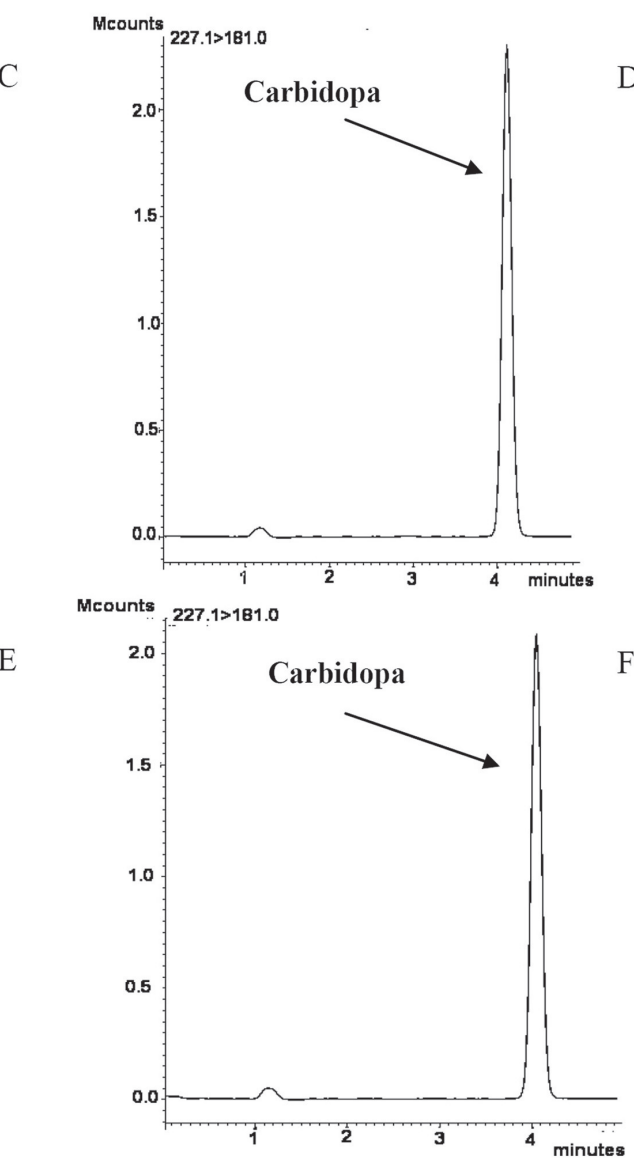

No interference peaks from endogenous compounds were observed at the retention time of the analyte and I.S. (Figures $2 \mathrm{~A}$ and 2B). The total run time was $5 \mathrm{~min}$, corresponding to an shorter analysis time than most of the analytical methods in the literature $e^{5,10,11,13,14}$.

Figure 2. SRM chromatograms of (A and B) blank plasma samples, (C and D) plasma samples spiked with 3-OMD and Carbidopa or (E and F) plasma collected from volunteers $6 \mathrm{~h}$ after oral administration of Levodopa 


\section{Linearity and limit of quantification}

A calibration curve was tested during the method validation and has shown to be linear over the concentration range of $50-4000 \mathrm{ng} / \mathrm{mL}$ with a weight factor $1 / \mathrm{x}^{2}$, which could cover all clinical concentrations of 3-OMD used in this study (Table 1). The linear equations of the calibration curves showed $r=0.998484$.

The lower limit of quantification (LLOQ) to 3-OMD in human plasma under our experimental conditions was $50 \mathrm{ng} / \mathrm{mL}$ (Figures $2 \mathrm{C}$ and $2 \mathrm{D}$ ), one of the lowest LLOQ reported in literature of which four of these were carried out by mass spectrometry (5). The mean precision and accuracy at LLOQ were 6.12 $\%$ and $99.04 \%$, respectively. With this LLOQ (50 ng/ $\mathrm{mL})$, the present method was very sensitive to detect 3 -OMD in human plasma even $120 \mathrm{~h}$ after a single oral administration of levodopa + benserazide $(200+50 \mathrm{mg})$ in this bioequivalence study.

Table 1. Precision and accuracy data of back calculated concentrations of calibration samples for 3-O-methyldopa in plasma (two replicates per batch)

\begin{tabular}{|c|c|c|c|c|}
\hline Analyte & $\begin{array}{l}\text { Nominal concentration } \\
\qquad(\mathbf{n g} / \mathbf{m L})\end{array}$ & $\begin{array}{c}\text { Observed concentration } \\
(\mathrm{ng} / \mathrm{mL}, \text { mean } \pm \text { S.D. })\end{array}$ & $\begin{array}{l}\text { Precision } \\
\text { (\% R.S.D.) }\end{array}$ & $\begin{array}{c}\text { Accuracy } \\
(\%)\end{array}$ \\
\hline \multirow{9}{*}{ 3-O-methyld } & 50 & $52.17 \pm 4.70$ & 9.01 & 104.33 \\
\hline & 100 & $91.54 \pm 6.68$ & 7.29 & 91.54 \\
\hline & 250 & $245.03 \pm 9.37$ & 3.83 & 98.01 \\
\hline & 500 & $491.06 \pm 16.71$ & 3.40 & 98.21 \\
\hline & & & & \\
\hline & 750 & $793.24 \pm 35.42$ & 4.59 & 105.77 \\
\hline & 1500 & $1546.68 \pm 22.32$ & 1.44 & 103.11 \\
\hline & 3000 & $3088.94 \pm 98.09$ & 3.18 & 102.96 \\
\hline & 4000 & $3845.21 \pm 91.60$ & 2.38 & 96.13 \\
\hline
\end{tabular}

S.D. = standard deviation; R.S.D. = relative standard deviation

\section{Precision and accuracy of quality control Standards}

Intra-batch, inter-batch precision and accuracy were evaluated by analyzing eight replicate quality control samples at four different concentration levels of $50,100,1500$ and $3000 \mathrm{ng} / \mathrm{mL}$ over three validation days. Full results are shown in Table 2, where it could be seen that the intra-batch precision measured by coefficient of variation, $\mathrm{CV}$, was $6.12 \%, 3.04 \%, 3.28 \%$ and $3.55 \%$, respectively. The precision and accuracy were according to the acceptable criteria recommended by Anvisa ${ }^{22}$. The precision at each concentration level did not exceed a CV of $15 \%$ and its accuracy is within the range established (i.e. 85 - $115 \%$ ) for each concentration level tested.

\section{Recovery}

The mean extraction recoveries of 3-OMD $(n=8)$ was $85.57 \%, 88.57 \%, 88.17 \%$ at concentrations of 50 ,
1500 and $3000 \mathrm{ng} / \mathrm{mL}$, respectively and was $92.40 \%$, $87.11 \%, 87.82 \%$ for CBDP (I.S) (Table 2).

Table 2. Precision, accuracy and recovery data for the assay of 3-O-methyldopa by LC-MS/MS

\begin{tabular}{lcccc}
\hline \multicolumn{1}{c}{$\begin{array}{c}\text { Validation } \\
\text { parameters }\end{array}$} & \multicolumn{4}{c}{$\begin{array}{c}\text { 3-O-methyldopa quality control } \\
\text { concentration }(\mathbf{n g} / \mathbf{m L})\end{array}$} \\
\hline Precision (R.S.D. \%) & 50 & 100 & 1500 & 3000 \\
Intra-run (n=8) & 6.12 & 3.04 & 3.28 & 3.55 \\
Inter-run(n=24) & ------ & 5.31 & 2.28 & 0.55 \\
Accuracy (\%) & & & & \\
Intra-run (n=8) & 99.04 & 94.80 & 101.96 & 100.85 \\
Inter-run(n=24) & ------ & 90.59 & 100.52 & 100.76 \\
& & & & \\
& ---- & 85.57 & 88.57 & 88.17 \\
\hline
\end{tabular}


Stability (Freeze- thaw, Auto sampler, Room temperature, Long term, standard solutions)

The stability of 3-OMD was evaluated after 8 freeze-thaw $\left(-70^{\circ} \mathrm{C}\right.$ to room temperature) cycles. No significant degradation of 3-OMD was observed even after a $48 \mathrm{~h}$ of storage period in the autosampler tray $(+7$ ${ }^{\circ} \mathrm{C}$ ), and the final concentrations of 3-OMD ranged from 1.04 to $3.95 \%$. In addition, the long-term stability of 3 -OMD in QC samples after 683 days of storage at $-70^{\circ} \mathrm{C}$ was also evaluated. The concentrations ranged from -6.46 $\%$ to $7.73 \%$ (Table 3 ). These results confirmed the stability of 3-OMD in human plasma for at least 683 days at -70 ${ }^{\circ} \mathrm{C}$. The stability of standard working solutions of 3-OMD and CBDP (IS) were evaluated for periods of 6 hours under the temperature of $+22^{\circ} \mathrm{C}$ and under refrigeration at $-70^{\circ} \mathrm{C}$. In these two studies no significant degradation were observed for both, the analyte or internal standard (Table 4).

Table 3. Stability of human plasma samples of 3-O-methyldopa under various storage conditions $(\mathrm{n}=8)$

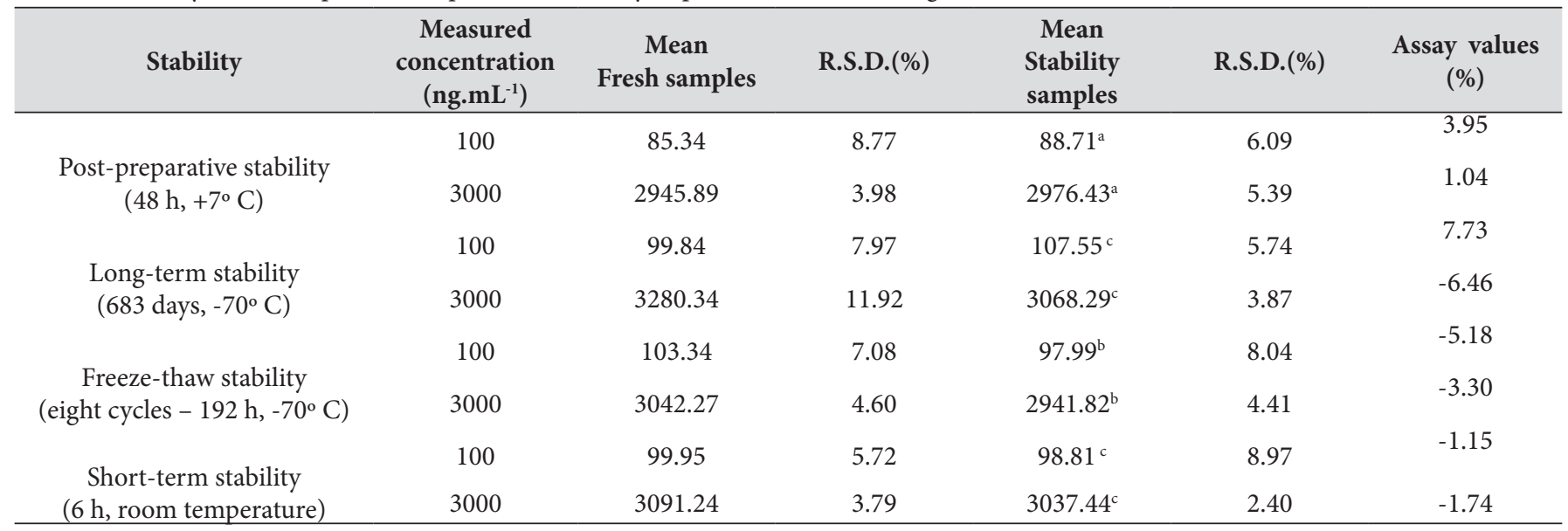

${ }^{\mathrm{a}}$ After 48 hours. ${ }^{\mathrm{b}}$ after 192 hours. ${ }^{\mathrm{c}}$ after 6 hours, ${ }^{\mathrm{a}}$ Mean of eight replicates, ${ }^{\mathrm{b}} \mathrm{RSD}=$ Relative standard deviation

Table 4. Stability of standard solutions of 3-O-methyldopa and carbidopa (IS) under various storage conditions $(n=8)$

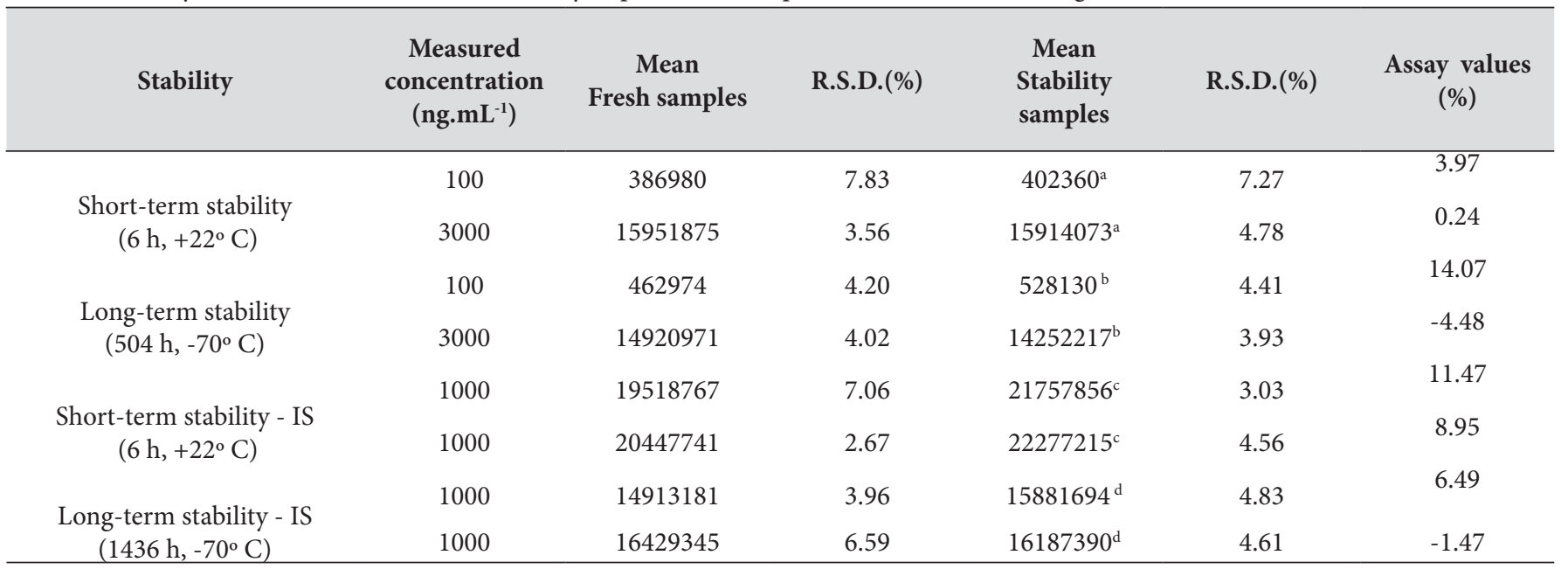

${ }^{\mathrm{a}, \mathrm{c}}$ After 6 hours. ${ }^{\mathrm{b}}$ after 504 hours. ${ }^{\mathrm{c} a f t e r} 6$ hours, ${ }^{\mathrm{a}}$ Mean of eight replicates, ${ }^{\mathrm{d}}$ after 1436 hours, ${ }^{\mathrm{b}} \mathrm{RSD}=$ Relative standard deviation 
Martins HF, Pinto DP, Nascimento VA, Marques MAS, Amendoeira FC. Development of a HPLC/MS/MS methodology for determining 3-O-methyldopa in human plasma and its application in a bioequivalence study Rev Inst Adolfo Lutz. São Paulo, 2014; 73(1):96-105.

\section{Application to a bioequivalence study in healthy subjects}

The analytical method was validated and used in the bioequivalence study of two formulations of levodopa + benzerazide. The curves showing the mean of 3-OMD plasma concentrations of 60 healthy volunteers versus time, after administration of reference and test preparations, are shown in Figure 3. The final results confirmed that the two preparations are bioequivalent according to their rate of absorption and elimination.

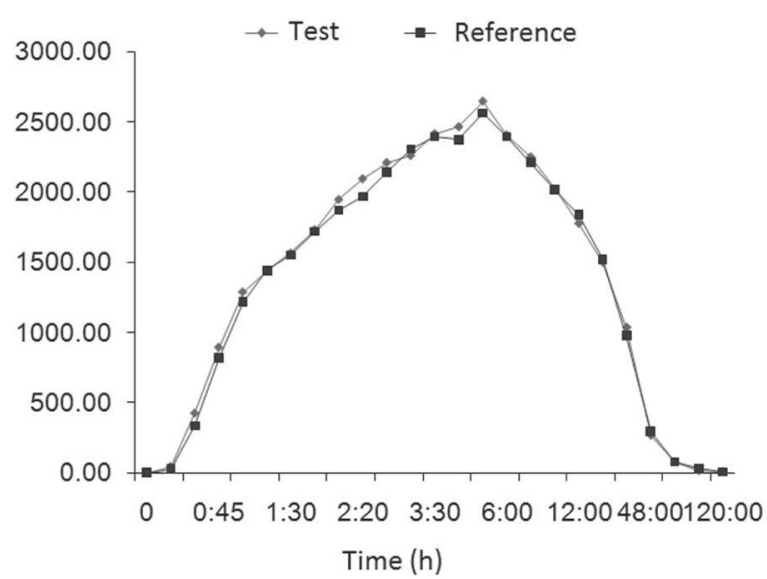

Figure 3. Plasma concentration-time curve of 3-OMD after the oral administration of a single dose of reference and test formulations. (levodopa $200 \mathrm{mg}$ + benserazide $50 \mathrm{mg}$ ) in 60 healthy volunteers

\section{CONCLUSION}

A HPLC-MS/MS method for the quantification of metabolite 3-OMD in human plasma was developed and validated and also was successfully applied to a bioequivalence study of two levodopa+benserazide formulations. The described method showed good specificity, precision, accuracy and linearity over the range of $50-4000 \mathrm{ng} / \mathrm{mL}$. This method provided a simple sample preparation using protein precipitation with perchloric acid. The established LLOQ of $50 \mathrm{ng} / \mathrm{mL}$ was adequate to determine the 3-OMD concentrations in human plasma until $120 \mathrm{~h}$ after oral administration of levodopa + benserazide $(200+50 \mathrm{mg})$ formulations.

No significant interferences caused by endogenous compounds were observed. The method was successfully applied to demonstrate the bioequivalence of test and reference formulation in a pharmacokinetic study and resents a small run time and high selectivity and sensitivity.

\section{ACKNOWLEDGEMENTS}

The authors gratefully acknowledge all volunteers, analysts, and technicians of laboratory with participated in this study. Thanks are due to Fiocruz and CNPq for financial support (407563/2012-1/CNPq).

\section{REFERENCES}

1. Bugamelli F, Marcheselli C, Barba E, Raggi MA. Determination of L-dopa, carbidopa, 3-O-methyldopa and entacapone in human plasma by HPLC-ED. J Pharm Biomed Anal.2011;54(3):562-7.

2. Galvan A, Wichmann T. Pathophysiology of parkinsonism. Clin Neurophysiol.2008;119(7):1459-74.

3. Keller GA, Czerniuk P, Bertuola R, Spatz JG, Assefi AR, Di Girolamo G. Comparative bioavailability of 2 tablet formulations of levodopa/benserazide in healthy, fasting volunteers: a singledose, randomized-sequence, open-label crossover study. Clin Ther.2011;33(4):500-10.

4. Ensafi A-A, Arabzadeh A, Karimi-Maleh H. Sequential determination of benserazide and levodopa by voltammetric method using chloranil as a mediator. J Braz Chem Soc.2010;21(8):1572-80.

5. Cesar IC, Bastos LF, Godin AM, Coelho M de M, Araujo DP, de Fatima A, et al. Simultaneous quantitation of nicorandil and its denitrated metabolite in plasma by LC-MS/MS: application for a pharmacokinetic study. J Mass Spectrom.2011;46(11):1125-30.

6. Lee ES, Chen H, King J, Charlton C. The role of 3-O-methyldopa in the side effects of L-dopa. Neurochem Res.2008;33(3):401-11.

7. Miller JW, Shukitt-Hale B, Villalobos-Molina R, Nadeau MR, Selhub J, Joseph JA. Effect of L-Dopa and the catechol-Omethyltransferase inhibitor Ro 41-0960 on sulfur amino acid metabolites in rats. Clin Neuropharmacol.1997;20(1):55-66.

8. Longhi JG, Perez E, Lima JJd, Cândido LMB. In vitro evaluation of Mucuna pruriens (L.) DC. antioxidant activity. Braz J Pharm Sci.2011;47(3):535-44.

9. César IC, Byrro RMD, Cardoso FFdSeS, Mundim IM, Teixeira LdS, Gomes SA, et al. Development and validation of a highperformance liquid chromatography- electrospray ionizationMS/MS method for the simultaneous quantitation of levodopa and carbidopa in human plasma. J Mass Spectrom.2011;46:943-8.

10. Lv L, Jiang W, Zhou S, Huang X, Shi X, Lv C, et al. LC-MSMS Simultaneous Determination of L-Dopa and Its Prodrug L-Dopa n-Pentyl Ester Hydrochloride in Rat Plasma. Chromatographia.2010;72(3):239-43.

11. Jiang W, Lv L, Zhou S, Huang X, Shi X, Lv C, et al. Simultaneous determination of L-dopa and its prodrug (S)-4-(2-acetamido3-ethoxy-3-oxopropyl)-1,2-phenylene diacetate in rat plasma by high-performance liquid chromatography-tandem mass spectrometry and its application in a pharmacokinetic study. J Pharm Biomed Anal.2010;53(3):751-4.

12. Jonkers N, Sarre S, Ebinger G, Michotte Y. Benserazide decreases central AADC activity, extracellular dopamine levels and levodopa decarboxylation in striatum of the rat. J Neural Transm.2001;108:559-70. 
13. Karimi M, Carl JL, Loftin S, Perlmutter JS. Modified highperformance liquid chromatography with electrochemical detection method for plasma measurement of levodopa, 3-O-methyldopa, dopamine, carbidopa and 3,4-dihydroxyphenyl acetic acid. J Chromatogr B: Anal Technol Biomed Life Sci.2006;836(1-2):120-3.

14. Muzzi C, Bertocci E, Terzuoli L, Porcelli B, Ciari I, Pagani R, et al. Simultaneous determination of serum concentrations of levodopa, dopamine, 3-O-methyldopa and alpha-methyldopa by HPLC. Biomed Pharmacother.2008;62(4):253-8.

15. Tolokan A, Klebovich I, Balogh-Nemes K, Horvai G. Automated determination of levodopa and carbidopa in plasma by highperformance liquid chromatography-electrochemical detection using an on-line flow injection analysis sample pretreatment unit. J Chromatogr B: Biomed Sci Appl.1997;698(1-2):201-7.

16. Kim TH, Cho KH, Jung WS, Lee MS. Herbal Medicines for Parkinson's Disease: A Systematic Review of Randomized Controlled Trials. PLoS ONE.2012;7(5):e35695.

17. Massano J, Garrett C. Deep brain stimulation and cognitive decline in Parkinson's disease: a clinical review. Front Neurol.2012;3(66):1-13.

18. PanL,GuoY,LiZ, ChenJ,JiangT, YuY.SimultaneousDetermination of Levodopa, Benserazide and 3-O-Methyldopa in Human Serum by LC-MS-MS. Chromatographia.2010;72(7):627-33.

19. Bedor DCG, Filho JHdS, Ramos VLS, Gonçalves TM, Sousa CEMd, Santana DPd. A sensitive and robust LC-MS/MS method with monolithic column and electrospray ionization for the quantitation of efavirenz in human plasma: application to a bioequivalence study. Quím Nova 2011;34(6):950-5 .
20. Dalmora SL, Sangoi MdS, Nogueira DR, D’Avila FB, Moreno RA, Sverdloff CE, et al. Determination of phenobarbital in human plasma by a specific liquid chromatography method: application to a bioequivalence study. Quím Nova. 2010;33(1):124-9.

21. Igarashi K, Hotta K, Kasuya F, Abe K, Sakoda S. Determination of cabergoline and L-dopa in human plasma using liquid chromatography-tandem mass spectrometry. J Chromatogr B.2003;792:55-61.

22. Brasil. Agência Nacional de Vigilância Sanitária (ANVISA). Resolução RE no 899, de 29 de maio de 2003.Aprova o Guia para validação de métodos analíticos e bioanalíticos. Diário Oficial da União Brasília (DF); 2 jun 2003; Seção 1

23. Brasil. Agência Nacional de Vigilância Sanitária (ANVISA). Resolução RDC no 27, de 17 de maio de 2012. Dispõe sobre os requisitos mínimos para a validação de métodos bioanalíticos empregados em estudos com fins de registro e pós-registro de medicamentos. Diário Oficial da União, Brasília (DF); 22 mai 2012; seção 1

24. Saxer C, Niina M, Nakashima A, Nagae Y, Masuda N. Simultaneous determination of levodopa and 3-O-methyldopa in human plasma by liquid chromatography with electrochemical detection. J Chromatogr B: Analyt Technol Biomed Life Sci.2004;802(2):299-305. 